\title{
Age And Effective Human Resource Management
}

\author{
Oluoch Mercy Florah,
}

University of Nairobi,

School of Business Department of Business Administration, Kenya

Doi:10.19044/esj.2019.v15n34p125 URL:http://dx.doi.org/10.19044/esj.2019.v15n34p125

\begin{abstract}
This article examines the implications of an aging workforce for human resource management (HRM). It first looks at the theories relevant to understanding age-related changes at work, including lifespan development theories, changes in work outcomes, and the social context for age (e.g., age stereotyping). Drawing from social-identity theory, human capital theory, role theory, jobs demand theory, relational demographic theory and social conservation of resource theory, theoretically the argument is that, in agediverse companies, age-based subgrouping processes occur, favoring a shared perception of a negative age-discrimination climate. This perceived negative age-discrimination climate in turn negatively relates to organizational performance. It then considers the ways that organizations can keep their employees - including those who are aging - satisfied, engaged, productive, and healthy in their jobs in terms of traditional HR practices like recruitment and selection, training, and occupational safety and health and implications of age in human resource decisions..
\end{abstract}

Keywords: Age, Human Resource management, Theories of HR on age

\subsection{Introduction}

Age diversity is a collective property present in almost all collective entities, such as families, sport teams, and work groups with members of varying ages. Only recently have scholars started to investigate age as a source of diversity processes and outcomes at the organizational level of analysis (Kunze et al., 2011). The demographic changes occurring in most industrialized countries present an urgent challenge for many organizations today. Companies are confronted with the fact that their workforce is getting both older and more age diverse due to the aging of their employees and shortages in the labour pool (Baltes and Finkelstein, 2011). Age is understood in terms of chronological age, referring to one's calendar age. However, the concept of age is multidimensional. For example, Sterns and Doverspike (1989) has given the often-cited five-fold distinction of age. He argues that in 
addition to chronological age there is functional age, psychosocial age, organizational age and lifespan age.

An alternative method of measuring age is work ability (Tepas and Barnes-Farrell, 2002), emphasizes the point that the ability to work should not only be seen in terms of changes in a person's functioning, but rather a process of human resources (physical, mental and social capacities, health, education and competence, values, attitudes, and motivation) in relation to work demands, the work environment and management (Ilmarinen, 2006).

\subsection{Theories Underpinning the Study}

There are several theories that underpin the study of age factors in human resource management. Amongst the theories discussed include: relational demography theory, human capital theory, social identity theory, role theory, conservation of resource theory and jobs demand control theory.

\subsubsection{Relational Demography Theory}

Relational demography theory is often used to explain how age diversity affects individuals in the workplace. The theory highlights the interaction between individual demographic characteristics and the social context (Riordan and Shore, 1997). Relational demography is guided by the assumptions that perceived similarity is strongly related to interpersonal attraction and that positive social identity and self-esteem are achieved by finding those categorized as socially similar to oneself to be attractive (Tajfel and Turner, 1986). Relational demography theory suggests assessed level of similarity or dissimilarity affects an individual's work-related attitudes and behaviors. Greater levels of similarity between the individual and coworkers should lead to increased attraction and liking and result in more positive work outcomes like positive job attitudes and increased in-role and extra-role performance (Tsui et al., 2002). Alternatively, greater levels of dissimilarity are argued to have negative effects on work experiences and work attitudes (Shore et al. 2003). Age-specific relational demography research has generally supported this similarity/dissimilarity hypothesis (Shore and Goldberg, 2005).

\subsubsection{Human Capital theory}

Human capital theory is concerned with the accumulated knowledge, skills, and abilities of organizational members, including both explicitly manifested behaviors and more tacit skills that may be more difficult to articulate and pass along to other members (Crook et al., 2011). Human capital may be tallied from a range of employee characteristics such as education and job experience and has been shown meta-analytically to relate to firm performance (Crook et al., 2011). It can also be examined at both the individual and organizational levels (Ployhart and Moliterno, 2011). One 
conclusion drawn by Crook et al. from their meta-analysis is that certain types of human capital can be of differential value to different firms and conditions; that is, all capital is not created equal. In the case of age at work, we observe that older workers may be seen as a substantial repository for human capital. Although little empirical work has directly addressed the issue of human capital in the aging workforce, this all suggests that firms need to identify their most critical human capital, often embodied in their older workers, and find ways either to keep such employees or pass along their skills and abilities to other workers through knowledge management systems (Argote, 2012).

\subsubsection{Social Identity Theory}

Social identity theory as postulated by Tajfel (1974) had two fundamental assumptions: (a) social (i.e., group) membership is a part of an individual's self-definition and (b) individuals need to achieve a positive selfimage. It also purports that positive identity is derived from favorable comparisons made between one's in-group and relevant out-groups (Tajfel and Turner, 1986). If one identifies with an age group and perceives that age group is valued and respected at work, this may lead to positive outcomes such as increased self-efficacy and well-being. However, because of age stigmatization within certain contexts, to be a "younger worker" or an "older worker" may mean being a member of a devalued group in the workplace. The negative social identity related to age group membership may lead workers to experience decreased satisfaction, engagement, and empowerment (Desmette and Gaillard, 2008).

\subsubsection{Conservation of Resource Theory}

Conservation of resources theory as postulated by Hobfoll, (1989, 2001) is used to understand motivation and stress across the lifespan. According to COR, people fundamentally seek to obtain, maintain, and protect valued resources. Resources can refer to a wide range of objects (e.g., house, car), personal characteristics (e.g., self esteem), conditions (e.g., status, a valued work role), and energies (e.g., physical or emotional energy, time) that are valued by the individual or that serve as a means of attaining these resources. COR theory posits that strain results from threatened or actual loss of resources. An example of a workplace condition resource would be age diversity climate (e.g., Boehm et al., 2013) such that employees value the condition of an environment that supports older workers. Social support could be considered as a personal characteristic resource because it promotes a positive sense of self and facilitates resilience under stressful circumstances (Hobfoll, 1989). 


\subsection{Approaches to Conceptualizing the Aging of Workers}

Kanfer and Ackerman (2004) discussed the approaches to conceptualizing the aging of workers which include chronological age, functional or performance-based age, psychological age, organization age and lifespan age as discussed below.

\subsubsection{Chronological Age}

It refers to one's calendar age. It is actual amount of time a person has been alive. The number of days, months or years a person has been alive does not change, regardless of how healthy a lifestyle one lives. - even one filled with great exercise and nutrition habits - they are living.

\subsubsection{Functional or Performance-Based Age}

It is related to a worker's performance, and recognizes that there is great variation in individual abilities and functioning at similar and different ages. Kanfer and Ackerman (2004) refer in this context to gains and losses. Aging is associated with losses in both physical and cognitive abilities (Baltes, 1997; Verhaeghen et al, 2003). Losses occur, for example, in physical strength and in fluid intelligence, such as working memory, abstract reasoning, attention, and processing of new information. However, aging brings gains as well. Gains occur, for example, in crystallized intelligence, such as general knowledge, extent of vocabulary, and verbal comprehension (Ackerman, 1996).

\subsubsection{Psychosocial Age}

It is based on the self and the social perception of age. The selfperception of age refers to subjective age, which refers to how old an individual feels, looks and acts, with which age cohort the individual identifies, and how old the person desires to be (Kaliterna et al, 2002). Furthermore, the self-perception of age involves perceptions of time, which shift from emphasizing the "life lived from birth" (past self-image) to the "life left until death" (future sense of self) ( Neugarten, 1968) and from an openended future time perspective (FTP) to a more limited FTP (Carstensen, 1995, 2006). The social perception of age involves age norms applied to an individual with respect to an occupation, company, or society, and social attitudes that are held toward older workers or the perceived attributes and stereotypes of older workers.

\subsubsection{Organizational Age}

It refers to the aging of individuals in their work role, jobs and organizations. With age, employees have more job knowledge, work experience and occupational expertise (Quinones et al, 1995). Organization 
and job tenure and career stage are important indicators of organizational age. According to Super's (1957) Career Development Model, employees pass through three stages in their career before they start detaching from work. First, employees pass through the trial stage, in which their primary concerns are to identify their interests and capabilities, and to define their professional role or self-image (Ornstein et al, 1989). Subsequently, in the establishment stage, employees are concerned with moving upward and mastering their identified area of interest. In the final stage, employees try to maintain their self-concept, hold on to their earlier achieved accomplishments, and maintain interest in the job (maintenance stage).

\subsubsection{Lifespan Age}

It borrows from a number of the above approaches, but allows for the possibility life expectancy at birth reflects the overall mortality level of a population. It summarizes the mortality pattern that prevails across all age groups in a given year - children and adolescents, adults and the elderly of behavioral change at any point in the life cycle, resulting for example from unique career and life stage changes. (De Lange et al., 2006).

\subsection{Age Stereotyping}

Butler (1975) defined ageism as the systematic stereotyping of and discrimination against older people because they are old, just as racism and sexism accomplished this with skin colour and gender. He further observed that the workplace as a microcosm of society reflects the stereotypes and biases that are part of the national social environment. When age biases negatively affect workplace decisions about employment, termination, retirement, benefits, training and promotion opportunities, age discrimination is in action.

An assumption of the workplace age stereotype research is that agerelated stereotypes affect how workplace decisions are made, such as who is offered a training opportunity or a challenging job assignment or who is hired for a particular job (Perry et al, 1996). Empirical research has identified a variety of stereotypes associated with older workers, with older workers generally viewed more negatively than younger workers (Posthuma and Campion 2009). This issue of negative stereotypes of older workers was recently the focus of a statement by the Society for Industrial and Organizational Psychology (2013) to the United Nations on the rights and dignity of older workers. Posthuma and Campion (2009) identified five major categories of negative older worker stereotypes, including having poorer performance, being resistant to change, having lower ability to learn, having shorter tenure, and being more costly. However, meta-analytic evidence ( $\mathrm{Ng}$ and Feldman, 2012) suggests that most stereotypes of older workers, other 
than their being less willing to participate in training and career development activities, are untrue. Unfortunately, negative age stereotypes can affect personnel decisions about older workers (Bal et al., 2011).

Younger worker stereotypes indicates that younger workers are perceived as being less trustworthy, having less loyalty to organizations, and as performing fewer individually focused organizational citizenship behaviors (Truxillo, McCune, et al., 2012). Arguably, the scarcity of research investigating younger worker stereotypes could be attributed to the assumed negative stereotypes held about older workers and positive stereotypes held about younger workers (Avolio and Barrett, 1987). This potential interaction and interdependence of age-related changes adds a level of complexity as to how age stereotypes may function in the workplace. Moreover, most of the workplace age stereotyping literature has focused on explicit age stereotypes, generally ignoring the possibility of implicit, unconscious workplace age stereotypes (Greenwald et al., 2002).

\subsection{Age Factor in HRM Decisions}

A number of HR decisions are made based on the age factors. These HR decisions and age factors are discussed below.

\subsubsection{Age Factor in Recruitment}

Recruitment refers to the actions organizations take to generate applicant pools, maintain viable applicants, and encourage desired candidates to join those organizations (Dineen and Soltis 2011). One of the challenges that organizations face is how to attract all types of talent, specifically that which is associated with both younger and older workers. There is a tendency of organizations setting an age limit for different levels and cadres of employment. An example is setting a maximum age of 27 years for management trainees or a minimum age of 35 for senior management staff. All this is negative discrimination on the basis of age. Snape and Redman (2003) argue that discrimination for being too young is at least as common as that for being too old. Both forms of discrimination adversely affect commitment to the organization and hence it could be argued that this eventually affects performance.

\subsubsection{Age Factor in Selection}

Employee selection refers to the process of choosing an individual to fill a particular job in an organization. This process is done by gathering information about applicants through a variety of procedures, such as application forms, written or performance tests, background or reference checks, and interviews. These procedures (and others) are often used in combination, and the data gathered are then combined judgmentally (e.g., by 
subjective interviewer ratings) mechanically (e.g., with a formula to combine scores on various selection tests), or through a mixture of both methods to form the basis of the selection decision (Cascio and Aguinis, 2011).

Because age is associated with the accumulation of disabilities, agediverse applicant pools may present an additional legal challenge for fair selection processes. In an age-diverse society with its concomitant age-diverse applicant pools, a number of hiring issues emerge about the fairness of hiring decisions. These fairness issues can be categorized into three: (a) age bias and stereotyping, (b) the potential for mean differences on selection procedures (adverse impact) by age, and (c) differential validity of selection procedures for different age groups (Bruyere, 2006).

\subsubsection{Age Factor in Job Placement}

Job placement refers to successfully fitting individuals to jobs that allow them to utilize their strengths and perform successfully at work. The types of jobs that are best-fitting for individuals later in their careers may be different from those that suit them well earlier on, due to changes that occur in skills, abilities, experiences, and preferences throughout the lifespan (Kanfer and Ackerman, 2004).

One frequent recommendation for helping middle-aged and older workers adapt to their physical and cognitive changes is to move into supervisory or management jobs. However, not all older workers can be supervisors - nor would many of them even want to be. Older and younger people will likely want and need different things from their jobs due not only to within-person, age-related changes but also due to different career expectations, norms, and non work responsibilities. Moreover, many older workers want to go into different jobs to pursue other interests or to utilize accumulated skills (Kanfer and Ackerman, 2004). Consistent with lifespan aging theories, older and younger workers appear to have different workrelated goals and motives (Baltes and Baltes, 1990).

According to Hertel et al (2013), very broadly, older workers will prefer and do best where they can apply their accumulated skills, do challenging work, and have some degree of autonomy. They obviously may not do well in work that requires high levels of fluid intelligence, although accumulated job knowledge will compensate for this in most jobs (Kanfer and Ackerman, 2004). With that in mind, jobs that can allow workers to apply their generativity motives, such as through mentoring, may be beneficial (Kanfer and Ackerman, 2004). Enriching older workers' jobs by simply giving them more to do would not seem beneficial (Zaniboni et al., 2013). Rather, given that many older workers also have significant job knowledge, they should be best able to know how to adapt their jobs to their own changes and yet get the work done. In fact, compared to their younger counterparts, older workers may 
have better outcomes (higher satisfaction and engagement, lower stress and turnover intentions) in jobs that allow them to reduce their breadth of tasks but apply their accumulated skills (Zaniboni et al., 2013).

\subsubsection{Age Factor in Trainings}

Training is defined as the planned and systematic activities designed to promote the acquisition of knowledge, skills, and attitudes. The goal of training is to create sustainable changes in behavior and cognition so that individuals possess the competencies they need to perform a job (Salas et al., 2012). It may be important to consider age when designing and implementing training programs in organizations because both cognition and motivation tend to change with age (Wolfson et al, 2014). While crystalized intelligence (learned or practiced knowledge) tends to remain stable or increase over time, fluid intelligence, such as cognitive processing speed and working memory capacity, tend to decrease with age (Kanfer and Ackerman, 2004). Particular types of training appear to be especially beneficial for older workers, such as error management training, which encourages trainees to accept making errors and treat mistakes as learning experiences Carter and Beier (2010).

According to Newton (2006), there is a clear association between age and the amount of training offered to and received by workers. Employees aged over 55 were less likely than younger or mid-life workers to take up opportunities for training that were made available and were more likely only to have received on the job training. As a result of this, young and middle aged employees get more opportunities for training and development as opposed to the elderly employees. In some organizations, there is a training policy that prohibits trainings of over six months for employees who have less than five years to retirement. In other institutions, older employees are favoured more when it comes to opportunities for workshop attendance and seminars. The age stereotype in learning is that older workers tend to have lower ability to learn. They are viewed not to have ability to develop new skills as well as younger workers. From a study conducted by Employee Benefits Research Institute (2007), it was observed that employers were investing in the training and development of young inexperienced workers rather than workers aged 55 years and above whose job tenure is three times longer (Kraiger, 2003).

\subsubsection{Age Factor in Employee Health and safety}

As health-care costs grow for organizations and employees, the importance of addressing employee health and safety becomes more apparent, particularly in the context of an aging workforce. Empirical evidence suggests that although older workers have poorer clinical health indicators (i.e., blood pressure, cholesterol, and body mass index) they do not have greater selfreported somatic and physical health complaints (Ng and Feldman, 2013). 
Further, the evidence also indicates that older workers do not have poorer mental health and do not have poorer health-related behaviors except for tobacco use (Ng and Feldman, 2013). An important factor in maintaining employee health is workplace safety. Meta-analytic evidence supports a positive relationship between chronological age and safety performance $(\mathrm{Ng}$ and Feldman, 2008). Indeed, research examining workplace accidents suggests that that older workers have fewer accidents, but when older workers are involved in an accident, the injuries are more destructive and require a longer recovery time (Sterns et al, 1985).

\subsubsection{Age Factor in Job Design}

According to Morgeson and Humphrey (2008), job design is the study, creation, and modification of the composition, content, structure, and environment within which jobs and roles are enacted. As such, it concerns who is doing the work, what is done at work, the interrelationship of different work elements, and the interplay of job and role enactment with the broader task, social, physical, and organizational context. Truxillo, Cadiz, et al. (2012) proposed that different job design characteristics, drawn from Morgeson and Humphrey's (2006) Work Design Questionnaire should have differential effects on job satisfaction, engagement, and performance, based on age. For example, they posited that older workers may be able to work autonomously because of their increased work experience and crystallized intelligence. In contrast, younger people workers may require less autonomy, as they have fewer accumulated job skills and crystallized intelligence (Kanfer and Ackerman, 2004).

\subsubsection{Age Factor in Teams}

A team refers to "two or more individuals who socially interact, possess one or more common goals, are brought together to perform organizationally relevant tasks, exhibit interdependencies with respect to workflow, goals and outcomes, have different roles and responsibilities, and are together embedded in an encompassing org system, with boundaries and linkages to the broader system context and task environment" (Kozlowski and Ilgen, 2006). According to Cannon-Bowers and Bowers (2011), the essence of teamwork is interdependence of action, shared responsibility, and common, meaningful goals. Team composition is an important consideration for organizations, as it affects all other aspects of team functioning. Individual characteristics are only useful to the extent that they combine optimally with other members on the team. The average age, as well as the age composition of teams, is important in this respect. Research on age diversity in teams shows that team processes (such as mutual learning, feedback, and decision making), and team performance (such as product quality, sick days, burnout, 
involvement, and satisfaction) are likely to be influenced by the age diversity of the team (Schalk et al., 2010).

Social identity theory (Tajfel, 1974) can be used to explain how grouplevel age composition affects work outcomes. It states that group membership is an important part of individuals' identity and that a positive self-image is necessary for well-being. According to Iweins et al. (2013), the dual identity model (based in social identity theory) posits that simultaneously maintaining an ingroup-outgroup distinction and building a super-ordinate identity in a cooperative encounter is conducive to more peaceful group interactions (Richter et al., 2006).

\subsubsection{Age Factor in Succession Planning}

Succession planning is process of identifying and selecting the employee within the organization based on their competencies, skills and attitudes, personality, behavior, extraordinary performance, highly motivated towards the work and positive approach towards the organization (Levesque, 2005) preparing them for attaining the new role within the organization (Garman and Glawe , 2004). HR manager's plays a crucial role in matching the future engagement/ requirements through resources available internally based on their capability and skills expressed during the current engagements within the organization (Stybel 1982). This process helps in identifying the individuals internally within the organization who will be eligible to take up the future / emerging opportunities in the company over a period of time (Charan et al, 2001).

\subsection{Implications of Age Factor in Human Resource Decisions}

First and foremost, age is a poor predictor of job performance. It should be noted that performance is not purely affected by one's age. Other factors may affect one's performance including health, family problems, the society's views, the nature of work, the work environment, equipment and apparatus of work among others. Secondly, it is misleading to equate physical and mental ability with age. People age at different rates. It is not guaranteed that the physical and mental ability will deteriorate at the same rate with age. Depending on one's living pattern, ageing will catch up in different rates for different people. Thirdly, more of the population than ever before are living active, healthy lives as they get older. This has resulted in older healthier workers than before. As a result, some older workers are even more active and proactive than the younger workers. Fourthly, age is rarely a genuine employment requirement factor. Regardless of one's age, he is able to perform to some extent and in his own ways. However, the idea of restricting on age for some selected positions is a matter of preference by an institution. Fifthly, society's attitudes may encourage compliance with outdated human resource 
practices regarding recruitment, promotion, training, redundancy and retirement. Lastly, reduced self-confidence, self-esteem and motivation, together with loss or reduction of financial independence for individuals and their dependents, are some of the harmful effects of age discrimination.

\subsection{Conclusion}

In practice, a number of employment decisions are made based on the age of the employees. In general, age can be seen as a social organizing principle, which defines individual employees as well as work groups. In addition, different age groups, both ageing and younger, gain identities and power in relation to other age groups. Organizations should hence regularly assess the age composition of their workforce to develop a sense of awareness and evaluate whether increased age diversity and age discrimination is a potential obstacle for performance. In order to fully utilize the age diversity in an organization, current HRM policies and practices should be analyzed in order to recognize possible ageist or age blind practices rooted in the organization. Managers may hold stereotypical views towards ageing employees which may hinder the change in an organization's cultural values. It may also seems that the rhetoric of the importance of age-friendly HR practices and policies may differ greatly from the actual HR practices used in the organization. Therefore, there is a need to shift from randomly used 'agefriendly' HR practices and policies to more integrated and strategically relevant HR practices in order to create workplaces in which each employee feels valued and ageing is not faced stereotypically.

With respect to the effects of age, we should tailor HR practices to reflect the age of individual workers. For example, HR practitioners should consider increasing teamwork (or mentoring roles), rewards (e.g., through increased recognition) or flexible work schedules for older workers since these HR practices seem likely to increase their positive work-related attitudes.

\section{References:}

1. Ackerman, P. L. (1996). A theory of adult intellectual development: Process, personality, interests, and knowledge. Intelligence, 22, 229259.

2. Argote, L. (2012). Organizational learning: Creating, retaining, and transferring knowledge. New York: Springer.

3. Armstrong-Stassen M. and Lee S. (2009) The effect of relational age on older Canadian employees' perceptions of human resource practices and sense of worth to their organization, The International Journal of Human Resource Management, Vol. 20, 8, pp. 17531769. 
4. Armstrong-Stassen, M., and Schlosser, F. (2011). Perceived organizational membership and the retention of older workers. Journal of Organizational Behavior 32: 319-344.

5. Anti-Ageism Taskforce. (2006). Ageism in America, New York: International Longevity Center - USA

6. Avolio, B. J., and Barrett, G. V. (1987). Effects of age stereotyping in a simulated interview.

Psychology and Aging 2: 56-63.

7. Bal, A. C., Reiss, A. E. B., Rudolph, C. W., and Baltes, B. B. (2011). Examining positive and negative perceptions of older workers: A meta-analysis. The Journals of Gerontology, Series B:Psychological Sciences and Social Sciences 66: 687-698.

8. Baltes, P. B. (1997). On the incomplete architecture of human ontogeny. Selection, optimization, and compensation as foundation of developmental theory. American Psychologist, 52, 366-380.

9. Baltes, B. B. and Finkelstein, L. M. (2011). 'Contemporary empirical advancements in the study of aging in the workplace'. Journal of Organizational Behavior, 32, 151-4.

10. Baltes, P. B., and Baltes, M. M. (1990). Psychological perspectives on successful aging: The model of selective optimization with compensation. In P. B. Baltes and M. M. Baltes (eds.). Successful aging: Perspectives from the behavioral sciences (pp. 1-34). New York: Cambridge University Press.

11. Boehm, S., Kunze, F., and Bruck, H. (2013). Spotlight on age diversity climate: The impact of age-inclusive HR practices on firm-level outcomes. Personnel Psychology.

12. Bruyère, S. (2006). Disability management: Key concepts and techniques for an aging workforce. International

13. Journal of Disability Management Research 1: 149-158. http://dx.doi.org/10.1375/jdmr.1.1.149

14. Butler, R. N. (1975). Why survive? Being old in America. San Francisco: Harper \& Row.

15. Cadiz, D. M. (2010). The effects of ageism climates and core selfevaluations on nurses' turnover intentions, organizational commitment, and work engagement. Unpublished doctoral dissertation, Portland State University,

16. Portland, OR.

17. Cannon-Bowers, J. A., and Bowers, C. (2011). Team development and functioning. In S. Zedeck (ed.),APA

18. handbook of industrial and organizational psychology, Vol. 1 (pp. 597-650). Washington, DC: American

19. Psychological Association. 
20. Carstensen, L. L. (1995). Evidence for a life span theory of socioemotional selectivity. Current Directions in

21. Psychological Science, 4, 151-156.

22. Carstensen, L. L. (2006). The influence of a sense of time on human development. Science, 312,

23. 1913-1915

24. Cascio, W. F., and Aguinis, H. (2011). Applied psychology in human resource management. 7 th ed. Upper Saddle River, NJ: Prentice Hall.

25. Carter, M., and Beier, M. E. (2010). The effectiveness of error management training with

26. working aged adults. Personnel Psychology 63: 641-675.

27. Charan. R, S. Drotter. S and J. Noel. J, (2001). The Leadership Pipeline: How to Build the Leadership Powered Company, John wiley \& sons publishers, San Francisco, GA: Jossey-Bass.

28. Crook, T. R., Todd, S. Y., Combs, J. G., Woehr, D. J., and Ketchen, D. J. (2011). Does human capital matter? A metaanalysis of the relationship between human capital and firm performance. Journal of Applied Psychology 96: 443-456

29. De Lange, A. H., Taris, T. W., Jansen, P. G. W., Smulders, P., Houtman, I. L. D., \& Kompier, M. A. J. (2006). Age as a factor in the relation between work and mental health: Results from the longitudinal TAS study. In J. Houdmont \& S. McIntyre (Eds.), Occupational health psychology: European perspectives on research, education and practice (Vol. 1, pp. 21-45). Maia, Portugal: ISMAI

30. Demerouti, E., Bakker, A. B., Nachreiner, F., and Schaufeli, W.B. (2001). The job demands- resources model of burnout. Journal of Applied Psychology 86: 499-512.

31. Dineen, B. R., and Soltis, S. M. (2011). Recruitment: A review of research and emerging directions. In S. Zedeck (ed.), APA handbook of industrial and organizational psychology, Vol. 2 (pp. 43-66). Washington, DC: American Psychological Association.

32. Garman A.N and Glawe. J, (2004). Succession Planning, Consulting Psychology Journal: Practice \& Research, Vol. 56(2), pp: 119- 128.

33. Greenwald, A. G., Banaji, M. R., Rudman, L. A., Farnham, S. D., Nosek, B. A., and Mellott, D.

S. (2002). A

34. unified theory of implicit attitudes, stereotypes, self-esteem, and selfconcept. Psychological Bulletin 109: 3-25.

35. Hammer, L. B., and Zimmerman, K. L. (2011). Quality of work life. In S. Zedeck (ed.), APA handbook of industrial and 
organizational psychology, Vol. II (pp. 399-431). Washington, DC: American Psychological Association.

36. Hertel, G., Thielgen, M., Rauschenbach, C., Grube, A., StamovRoßnagel, C., and Krumm, C.

(2013). Age

37. differences in motivation and stress at work. In C. Schlick, E. Frieling, and J. Wegge (eds.) Age- differentiated work systems (113-147). Berlin: Springer.

38. Hobfoll, S. E. (1989). Conservation of resources: A new approach at conceptualizing stress. American Psychologist

39. 44: 513-524.

40. Hobfoll, S. E. (2001). The influence of culture, community, and the nested-self in the stress process: Advancing conservation of resources theory. Applied Psychology: An International Review 50: $337-421$.

41. Ilmarinen, J. (2006). Towards a Longer Worklife - Ageing and the Quality of Worklife in the European Union. Finnish Institute of Occupational Health, Helsinki.

42. Jonker, B. and Ziekemeyer, M. (2005). 'Wake up call - human resource management (HRM): an orientation on

43. company models anticipating ageing'. International Congress Series, 1280, 371-6.

44. Kaliterna, L., Larsen, Z. P., \& Brkljacic, T. (2002). Chronological and subjective age in relation to work demands:

45. Survey of Croatian workers. Experimental Aging Research, 28, 39-49.

46. Kanfer, R., \& Ackerman, P. L. (2004). Aging, adult development, and work motivation. Academy of

47. Management Review, 29, 440-458.

48. Karasek, R. A. (1979). Job demands, job decision latitude, and mental strain: Implications for job redesign.

49. Administrative Science Quarterly 24: 285-308.

50. Katz, D., and Kahn, R. L. (1978). The social psychology of organizations. New York: Wiley.

51. Kooij, D., de Lange A., Jansen, P. and Dikkers, J. (2008). ”Older workers motivation to continue to work: five

52. meanings of age. A conceptual review", Journal of Managerial Psychology, Vol. 23, No. 4, pp. 364-394.

53. Kozlowski, S., and Ilgen, D. (2006). Enhancing the effectiveness of workgroups and teams. Psychological Science

54. in the Public Interest 7: 77-124.

55. Kraiger, K. (2003). Perspectives on training and development. In W. C. Borman, D. R. Ilgen, and R. J. Klimoski (eds.), Handbook of 
psychology. Vol. 12, Industrial and organizational psychology (pp. 171-192). Hoboken, NJ: Wiley.

56. Kunze, F., Boehm, S. and Bruch, H. (2011). 'Age diversity, age discrimination, and performance consequences $-\mathrm{a}$

57. cross organizational study'. Journal of Organizational Behavior, 32, 264-90.

58. Levesque L.L, (2005). Opportunistic hiring and employee fit, Human Resource Management,

59. Vol. 44(3), 2005, pp: 301-317.

60. Morgeson, F. P., and Humphrey S. E. (2006). The Work Design Questionnaire (WDQ): Developing and validatinga comprehensive measure for assessing job design and the nature of work. Journal of Applied Psychology 91: 1321- 1399.

61. Neugarten, B. L. (1968). Middle age and aging. Chicago: University of Chicago Press.

62. Newton, B. (2006). Training on age-diverse workforce, Industrial and Commercial Training 38(2):93-97

63. Ng, T. W.H., and Feldman, D. C. (2013). Employee age and health. Journal of Vocational Behavior 83: 336-345.

64. Ogden, Zsidisin and Hendrick (2002). Factors That Influence Chief Purchasing Officer Compensation,The Journal of Supply Chain Management, Vol. 37(3), pp: 30-38.

65. Ornstein, S., Cron, W. L., \& Slocum, J. W. (1989). Life stage versus career stage: A comparative test of the theories of Levinson and Super. Journal of Organizational Behavior, 10, 117-133

66. Perry, E. L., Dokko, G., and Golom, F. (2012). The aging worker and person-environment fit. (187-212). In J.

67. W. Hedge and W. C. Borman (eds.), The Oxford handbook of work and aging. Oxford: Oxford University Press.

68. Ployhart, R. E., and Moliterno, T. P. (2011). Emergence of the human capital resource:

69. A multilvel model. Academy of Management Review 36: 127-150.

70. Posthuma, R. A., and Campion, M. A. (2009). Age stereotypes in the workplace: Common stereotypes, moderators, and future research directions. Journal of Management 35: 158-188.

71. Quinones, M. A., Ford, J. K., \& Teachout, M. S. (1995). The relationship between work experience and job

72. performance: A conceptual and meta-analytic review. Personnel Psychology, 48, 887-910

73. Riach, K. (2009). "Managing 'difference': understanding age diversity in practice", Human Resource Management

74. Journal, Vol. 19, No. 3, pp. 319-335. 
75. Riordan, C. M., and Shore, L. M. (1997). Demographic diversity and employee attitudes: An empirical examination

76. of relational demography within work units. Journal of Applied Psychology 82: 342-358.

77. Richter, A. W., West, M. A., Van Dick, R., and Dawson, J. F. (2006). Boundary spanners' identification,

78. intergroup contact, and effective intergroup relations. Academy of Management Journal 49: 1252-1269.

79. Salas, E., Tannenbaum, S. I., Kraiger, K., and Smith-Jentsch, K. A. (2012). The science of training and development

80. in organizations: What matters in practice. Psychological Science in the Public Interest 13: 74-101.

81. Schalk, R., Van Veldhoven, M., De Lange, A. H., De Witte, H., Kraus, K., Stamov-Rossnagel, C., et al. (2010).

82. Moving European research on work and ageing forward: Overview and agenda. European Journal of Work and

83. Organizational Psychology 19: 76-101.

84. Schaubroeck, J. Cotton, J. L., and Jennings, K. R. (1989). Antecedents and consequences of role stress:A covariance structure analysis. Journal of Organizational Behavior 10: 35-38.

85. Shore, L. M., and Goldberg, C. B. (2005). Age discrimination in the workplace. In R. L. Dipboye and A.Colella (eds.), Discrimination at work (pp. 203-225). Mahwah, NJ: Lawrence Erlbaum Associates.

86. Sterns, H. L., Barrett, G. V., and Alexander, R. A. (1985). Accidents and the aging individual. In J. E. Birren and

87. K. W. Schaie (eds.), Handbook of the psychology of aging, 2nd ed. (pp. 703-724). New York: Van Nostrand Reinhold.

88. Sterns, H.L. and Doverspike, D. (1989), "Aging and the retraining and learning process in organizations", in Goldstein, I. and Katze, R. (Eds.) Training and Development in Work Organizations, Jossey-Bass, San Francisco, CA, pp. 299-332.

89. Stybel L.J (1982). Linking Strategic Planning and Management Manpower Planning. California Management

90. Review, Vol. 25(1), pp: 48-56

91. Super, D. E. (1957). The psychology of careers: An introduction to vocational development. New York: Harper \& Brothers.

92. Tajfel, H. (1974). Social identity and intergroup behavior. Social Science Information 13: 65-93.

93. Tajfel, H., and Turner, J. C. (1986). An integrative theory of intergroup conflict. The social identity theory of intergroup behavior. In $\mathrm{S}$. 
Worchel and W. G. Austing (eds), Psychology of intergroup relations (pp. 33-47). Chicago: Nelson-Hall.

94. Tepas, D.I. and Barnes-Farrell, J.L. (2002), "Is worker age a simple demographic variable?", Experimental Aging Research, Vol. 28, pp. $1-5$.

95. Truxillo, D. M., Cadiz, D. M., Rineer, J. R., Zaniboni, S., and Fraccaroli, F. (2012). A lifespan perspective on

96. job design: Fitting the job and the worker to promote job satisfaction, engagement, and performance.

97. Organizational Psychology Review 2: 340-360.

98. Tsui, A. S., Porter, L. W., and Egan, T. D. (2002). When both similarities and dissimilarities matter: Extending

99. the concept of relational demography. Human Relations 55: 899-929. Uotinen, V. (2005), I'm as old as I feel. Subjective age in Finnish adults, Jyväskylä Studies in Education,Psychology and Social Research 276, Jyväskylän yliopisto, Jyväskylä.

100. Vantilborgh, T., Bidee, J., Pepermans, R., Willems, J., Huybrechts, G., and Jegers, M. (2013). From “"

101. getting"to"giving": Exploring age-related differences in perceptions of and reactions to psychological contract

102. balance. European Journal of Work and Organizational Psychology 22: 293-305.

103. Verhaeghen, P., Steitz, D., Sliwinski, M., \& Cerella, J. (2003). Aging and dual task performance: A meta- analysis. Psychology and Aging, 18, 443-460.

104. Wolfson, N., Cavanagh, T., and Kraiger, K. (2014). Older adults and technology-based instruction: Optimizing learning outcomes and transfer. Academy of Management Learning \& Education 13: 26-44.

105. Zaniboni, S., Truxillo, D. M., and Fraccaroli, F. (2013). Differential effects of task variety and skill variety on burnout and turnover intentions for older and younger workers. European Journal of Work and Organizational Psychology 22: 306-317. 